\title{
Effect of growth conditions on $\beta$-glucosidase production by local isolate of Aspergillus niger using rice bran substrate
}

\author{
SRI SUGIWATI ${ }^{1,2, \downarrow}$, MUHAMMAD HANAFI ${ }^{2,3}$, HANIFAH NURYANI LIOE ${ }^{1}$, \\ MAGGY THENAWIDJAJA SUHARTONO ${ }^{1}$ \\ ${ }^{1}$ Department of Food Science and Technology, Faculty of Agricultural Engineering and Technology, Institut Pertanian Bogor. Jl. Lingkar Akademik, \\ Kampus IPB Darmaga, Bogor 16680, West Java, Indonesia \\ ${ }^{2}$ Research Center for Chemistry, Indonesian Institute of Sciences. Gd. 452 Kawasan PUSPIPTEK, Serpong, Tangerang Selatan 15314, Banten, Indonesia. \\ Tel.: +62-21-7560929, Fax.: +62-21-7560549, ^email: sri_sugiwati@ yahoo.co.id. \\ ${ }^{3}$ Faculty of Pharmacy, Universitas Pancasila. Jl. Srengseng Sawah, Jagakarsa, Jakarta Selatan 12640, Jakarta, Indonesia
}

Manuscript received: 2 June 2020. Revision accepted: 11 August 2020.

\begin{abstract}
Sugiwati S, Hanafi M, Lioe HN, Suhartono MT. 2020. Effect of growth conditions on $\beta$-glucosidase production by local isolate of Aspergillus niger using rice bran substrate. Biodiversitas 21: 4058-4066. $\beta$-Glucosidase is the family of glycosyl hydrolase that have potential role in various food industry, such as in tea, wine and vanilla industries to increase the aroma and production of isoflavone aglycons in soybean flour. The present work produced $\beta$-glucosidase from local isolate of Aspergillus niger InaCC F57 under solid-state fermentation (SSF) using rice bran substrate. Fermentation process was made in various conditions with respect to carbon source as substrate, initial $\mathrm{pH}$ of fermentation medium, incubation time, water to substrate ratio, fermentation temperature, and addition of Mandels mineral salts solution. The results showed that activity of $\beta$-glucosidase was best at, i.e., $2.45 \mathrm{U} / \mathrm{mL}$, with the use of rice bran as substrate. Furthermore, optimum condition for the highest production of $\beta$-glucosidase occurred at $\mathrm{pH} 2.0$, incubation time of 5 days, water to substrate ratio of 1.5: 1 , and incubation temperature of $32^{\circ} \mathrm{C}$. Additionally, in optimum fermentation conditions, production of $\beta$-glucosidase could be enhanced up to $26.22 \%$ with the presence of Mandels mineral salts solution as compared to the control.
\end{abstract}

Keywords: Aspergillus niger, fermentation condition, $\beta$-glucosidase, rice bran, solid-state fermentation

\section{INTRODUCTION}

Enzymes are biocatalysts to increase the rate of chemical reactions in various industries, such as food, feed, detergents, textiles, pharmaceuticals, and cosmetics. There are more than 500 industrial products that involve the use of enzymes. Demand for industrial enzymes is increasing due to increase in the need for enzymes for sustainable production processes (Kumar et al. 2014). Currently, almost $99 \%$ of the needs of enzymes (biocatalysts) for industries in Indonesia are still imported from abroad such as China, India, Japan, and parts of Europe. Enzyme requirements tend to increase every year and it is estimated that global market demand for enzymes increases by about $7.0 \%(2015$ - 2020) per year. Industrial enzyme consumption in Indonesia is estimated to reach 2500 tons with an import value of around 200 billion in 2017 with an average volume growth rate of $5-7 \%$ per year. A value large enough to encourage independence in producing national commercial enzymes (Kemenristekdikti 2017).

Cellulase is one of the widely used industrial enzymes and ranks third largest in the world. $\beta$-Glucosidase is part of the cellulolytic enzyme complex. $\beta$-Glucosidase $(\beta-D$ glucosidase glucohydrolase; EC 3.2.1.21) is the family of glycosyl hydrolase that catalyzes the selective cleavage of glucosidic linkages of alkyl and aryl $\beta$-glycosides, disaccharides and short-chain oligosaccharides (Krisch et al. 2010). The cellulolytic enzyme complex consists of a variety of hydrolytic and redox enzymes acting synergistically to convert cellulose into glucose. The hydrolases comprise endoglucanase (EC 3.2.1.4), cellobiohydrolases (EC 3.2.1.176), exoglucohydrolases (EC 3.2.1.74), and $\beta$-glucosidases (EC 3.2.1.21) (MaitanAlfenas et al. 2015). Endoglucanases hydrolyze $\beta-1,4-$ glucosidic linkages randomly in the middle of cellulose chain. Cellobiohydrolases are also known as exoglucanases continue the hydrolysis process along the cellulose chain and cleave off cellobiose units from the ends. In the final step, $\beta$-glucosidases are also known as $\beta$-glucoside glucohydrolases complete the cellulose hydrolysis by hydrolyzed cellobiose to glucose and also cleave off glucose units from cello-oligosaccharides (Binod et al. 2019).

$\beta$-glucosidase is currently produced using either submerged fermentation $(\mathrm{SmF})$ or solid-state fermentation (SSF) (Singhania et al. 2010). SSF offers an alternative for low-cost enzyme production and it has different advantages such as high productivity, cheap substrate utilization, low energy requirement. Moreover, under SSF conditions, there is minimal water output and lacking foam up which makes it economically feasible (Faisal and Benjamin 2016). SSF provides growth conditions that are similar to the environment to which filamentous fungi are naturally adapted. Better interaction between the microorganism and the substrate is achieved using SSF, which results in higher enzyme concentrations (Singhania et al. 2010). Another advantage of SSF is the use of abundant agro-industrial lignocellulosic wastes as carbon sources. 
Research on $\beta$-glucosidase has been more interesting in the last few years. This is due to potential roles of the enzymes in various biotechnological processes. In food technology, $\beta$-glucosidase has several applications, such as to increase the aroma quality of tea beverage (Zhang et al. 2020), production of isoflavone aglycons in soybean flour (Yang et al. 2014), and to catalyze hydrolysis of vanillin flavor precursor for releasing the aromatic aglycon and the generation of vanilla flavor components during the curing process (Rivera-Espinoza and Muriel 2013), and to increase the amount of monoterpenes and non-isoprenoids for aroma development in wines (Gonzales-Pombo et al. 2011). In the production of bioethanol from lignocellulosic biomass, $\beta$-glucosidase plays important role in hydrolyzing of cellobiose which is an intermediate compound from cellulose hydrolysis by endoglucanase and exoglucanase into glucose monomer (Singhania et al. 2013).

Most commercial cellulases are obtained from filamentous fungi such as Trichoderma, Penicillium, and Aspergillus (Zhao et al. 2018). Among them the Ascomycete genus Aspergillus has been extensively studied for the production of $\beta$-glucosidase (Sørensen et al. 2013). The genus Aspergillus has potential for enzyme industry, because almost all fungi of this genus synthesize cellulase (Mai et al. 2018). Production of $\beta$-glucosidase from different Aspergillus strains has been widely reported, such as Aspergillus niger (Zahoor et al. 2011), Aspergillus oryzae (Watanabe et al. 2016), Aspergillus terreus (Elshafei et al. 2011), Aspergillus fumigatus (Cao et al. 2015), Aspergillus saccharolyticus (Sørensen et al. 2014), Aspergillus ochraceus (Asha et al. 2016), and Aspergillus japonicus (da Silva et al. 2014). The use of A. niger as a source of $\beta$-glucosidase has been widely applied (Qian et al. 2012). A. niger has a long and extensively documented history of safe use for food enzyme production. These Aspergillus species have been used for fermentation of food more than 2 millennia and to manufacture food enzymes for over 50 years (Frisvad et al. 2018).

Lignocellulosic biomass residues such as wheat bran, sugarcane bagasse, rice straw, waste paper, fruit pomace, corn cob, and soybean can be used as carbon source and enzyme inducer during the cellulases production (Jampala et al. 2017; Irfan et al. 2017). These lignocellulosic residues are abundant, renewable, cheap, and readily procurable sources of nutrients for the growth of cellulases producing microorganisms (Saini et al. 2017).

The objective of this research was to produce $\beta$ glucosidase from local isolate of A. niger InaCC F57 and evaluate cultural conditions that responsible for its productivity. The isolate obtained from the Indonesian Culture Collection (InaCC), Research Center for Biology, Indonesian Institute of Sciences. The enzyme production was performed under solid-state fermentation using lignocellulosic biomass (rice straw, rice hull, rice bran and brown rice flour) as a substrate. The various factors that affect cultural conditions to maximum enzyme production including carbon source, initial $\mathrm{pH}$ of fermentation medium, fermentation incubation time, the ratio of water to substrate, fermentation temperature, and the presence of Mandels mineral salts solution were studied in the research.

\section{MATERIALS AND METHODS}

\section{Materials and reagents}

Rice straw, rice hull, rice bran, and brown rice flour were collected from local farmers in Karawang, West Java. Potato Dextrose Agar (PDA), sodium carbonate, $\mathrm{CuSO}_{4} .5 \mathrm{H}_{2} \mathrm{O}$, potassium sodium tartrate, Folin Ciocalteu reagent, Bovine Serum Albumin (BSA), sodium acetate, acetic acid, and $p$-nitrophenyl- $\beta$-D-glucopyranoside ( $p$ NPG) (Sigma Aldrich), Mandels mineral salts solution (g/L): urea 0.3, $\left(\mathrm{NH}_{4}\right)_{2} \mathrm{SO}_{4} 1.4, \mathrm{KH}_{2} \mathrm{PO}_{4} 2.0, \mathrm{CaCl}_{2} .2 \mathrm{H}_{2} \mathrm{O}$ $0.4, \mathrm{MgSO}_{4} .7 \mathrm{H}_{2} \mathrm{O} \quad 0.3$, peptone 1.0 , Tween $80 \quad 0.2$, $\mathrm{FeSO}_{4} .7 \mathrm{H}_{2} \mathrm{O} \quad 0.005, \mathrm{MnSO}_{4} .7 \mathrm{H}_{2} \mathrm{O} 0.0016, \mathrm{ZnSO}_{4} .7 \mathrm{H}_{2} \mathrm{O}$ $0.0016, \mathrm{CoCl}_{2} .6 \mathrm{H}_{2} \mathrm{O} 0.02$.

\section{Microorganism}

Local isolate of A. niger InaCC F57 was obtained from the Indonesian Culture Collection (InaCC), Research Center for Biology Indonesian Institute of Sciences, Cibinong, Bogor.

\section{Production and extraction of $\beta$-glucosidase}

Solid-state fermentation was carried out in Erlenmeyer flasks $(100 \mathrm{~mL})$ containing $10 \mathrm{~g}$ of substrate and $10 \mathrm{~mL}$ of aquadest. The medium was sterilized by autoclave at $121^{\circ} \mathrm{C}$ for 30 minutes. After sterilization, the medium was cooled and inoculated with $1 \mathrm{~mL}$ of spore suspension ( $10^{7}$ spores) of $A$. niger and incubated at $28^{\circ} \mathrm{C}$ for 7 days with initial fermentation $\mathrm{pH}$ of 6.0 . The spore of $A$. niger was determined by Hemocytometer. The enzyme was extracted by adding $50 \mathrm{ml}$ of sodium acetate buffer ( $50 \mathrm{mM}, \mathrm{pH} 5.0)$ to the Erlenmeyer flasks. The flasks were shaken on a rotary shaker at $120 \mathrm{rpm}$ for $1 \mathrm{~h}$ at $28^{\circ} \mathrm{C}$. The solution was filtered by muslin cloth to remove mycelia and the filtrate was centrifuged at $6000 \mathrm{rpm}$ for $10 \mathrm{~min}$ at $4^{\circ} \mathrm{C}$. The supernatant obtained was a crude extract of $\beta$-glucosidase and then was determined for its activity, protein content, and specific activity.

\section{Determination of optimum condition for $\beta$-glucosidase production}

The optimum condition for $\beta$-glucosidase production was determined by testing the factors that affect enzyme production, including carbon sources, initial $\mathrm{pH}$ of fermentation medium, fermentation incubation time, water to substrate ratio, incubation temperature and addition of Mandels mineral salts solution to fermentation medium.

\section{Effect of carbon sources on enzyme production}

Effect of various carbon sources namely, rice husk, rice straw, rice bran, and brown rice flour were determined by added $10 \mathrm{~mL}$ of water to $10 \mathrm{~g}$ of each carbon source. The medium of fermentation was incubated at $28^{\circ} \mathrm{C}$ for 7 days and initial $\mathrm{pH}$ of 6.0 .

\section{Effect of initial pH on enzyme production}

Effect of initial $\mathrm{pH}$ of fermentation medium was performed by adjusting initial fermentation medium $\mathrm{pH}$ in range $2.0,3.0,4.0,4.5,5.0,5.5,6.0$, and 7.0 using 1 
$\mathrm{mmol} / \mathrm{L} \mathrm{HCl}$ or $1 \mathrm{mmol} / \mathrm{L} \mathrm{NaOH}$. The medium of fermentation was incubated at $28^{\circ} \mathrm{C}$ for 7 days.

\section{Effect of incubation time on enzyme production}

Effect of fermentation incubation time was determined by incubating the fermentation medium at different times in range $1,2,3,4,5,6,7,8$, and 9 days with initial medium $\mathrm{pH}$ of 6.0 and incubation temperature of $28^{\circ} \mathrm{C}$.

\section{Effect of water to substrate ratio on enzyme production}

Effect of water to fermentation substrate ratio was performed by variation of aquadest volume $(5,10,15,20$, 25 , and $30 \mathrm{~mL}$ ) which added into $10 \mathrm{~g}$ substrate. The medium of fermentation was incubated at $28^{\circ} \mathrm{C}$ for 7 days and initial $\mathrm{pH}$ of 6.0 .

Effect of incubation temperature on enzyme production

Effect of incubation temperature was determined by incubating the fermentation medium at different temperature $\left(28,32\right.$, and $\left.36^{\circ} \mathrm{C}\right)$ with initial fermentation medium $\mathrm{pH}$ of 6.0 and incubation time of 7 days.

\section{Effect of Mandels mineral salts solution}

Effect of Mandels mineral salts solution to $\beta$ glucosidase production was determined by adding $15 \mathrm{~mL}$ of Mandels solution into $10 \mathrm{~g}$ of rice bran. The fermentation processes were performed in optimum fermentation conditions.

\section{$\beta$-Glucosidase assay}

$\beta$-glucosidase activity assay was performed according to Herr et al. (1978) using $p$-nitrophenyl- $\beta$-Dglucopyranoside ( $p$-NPG) as a substrate. The enzyme activity assay was contained $1.0 \mathrm{~mL}$ of $2 \mathrm{mM}$ solution of $p$ $\mathrm{NPG}$ in $0.05 \mathrm{M}$ sodium acetate buffer $(\mathrm{pH} 4.8)$. The reaction was started after incubated of $p$-NPG solution at $40^{\circ} \mathrm{C}$ for 5 minutes by the addition of $100 \mu \mathrm{L}$ of crude enzyme solution. After 10 minutes the reaction was stopped by addition of $2.0 \mathrm{~mL}$ of $1 \mathrm{M} \mathrm{Na}_{2} \mathrm{CO}_{3}$ solution. The absorbance of solution was read at $405 \mathrm{~nm}$. One unit (U) of $\beta$-glucosidase was defined as the amount of enzyme that catalyzes the hydrolysis of $p$-NPG to liberate $1 \mu \mathrm{mol}$ of $p$-nitrophenol per minute under assay conditions.

\section{Protein determination}

The protein contents of enzyme were measured by the Lowry method (1951) with bovine serum albumin (BSA) as standard.

\section{Analysis of cellulose, hemicellulose, and lignin}

Determination of cellulose, hemicellulose, and lignin contents of lignocellulosic biomass was carried out using the Chesson method (Datta 1981).

\section{Data analysis}

The experimental design used in this study is Completely Randomized Design (CRD). The reported data is the mean \pm SD for two replications of each treatment. Data were evaluated using One-Way Analysis of Variance (ANOVA) at significance level of $95 \%(p<0.05)$ in SPSS version 22. Significance difference between means was compared using Duncan test at $\alpha=0.05$.

\section{RESULTS AND DISCUSSION}

SSF refers to the process where microbial growth and product formation occurs on the surface of solid materials. This process involves the absence (or near absence) of free water; however, the moisture is absorbed to the solid substrate to support growth and microbial metabolism (Ang et al. 2013; Pirota et al. 2014). SSF is suitable for fungi growth because of its moisture content and permitting of the penetration of fungi mycelium through the solid substrates (Grover et al. 2013). A. niger is a filamentous fungus that is the most commonly used microorganisms in SSF because they are able to grow on solid materials with low water content (Shobana and Maheswari 2013).

There are several fermentation conditions on SSF process affecting cellulase production, i.e. carbon and nitrogen sources of production medium and physicochemical parameters such as moisture content, $\mathrm{pH}$, temperature, incubation time, particle size, and aerations (Polyanna et al. 2011; Manan and Webb 2017).

Determination of fermentation conditions for maximum $\beta$-glucosidase production was performed by examining the factors that affect enzyme production i.e. initial $\mathrm{pH}$ of fermentation medium, fermentation incubation time and temperature, water to substrate ratio, and addition of Mandels mineral salt solution. In our study, determination of optimum incubation conditions was carried out on medium without supplemented Mandels mineral salts solution. The addition of Mandels solution to the medium was carried out in the production of enzymes after the optimum fermentation conditions for $\beta$-glucosidase production are obtained. Compared to Qiant et al. (2012) which performed optimization of $\beta$-glucosidase production from A. niger AS 3.4309 under SSF. Optimum incubation conditions (initial $\mathrm{pH}$, incubation temperature, fermentation period) for fermentation process performed using optimum solid medium containing wheat bran supplemented with salt minerals $\mathrm{MgSO}_{4} .7 \mathrm{H}_{2} \mathrm{O}$ and $\mathrm{KH}_{2} \mathrm{PO}_{4}$.

\section{Effect of different carbon sources on enzyme production}

The fungus A. niger used plant biomass polysaccharides as carbon source for fungal growth by degrading these compounds into monomeric sugars. Furthermore, these monomeric sugars were transported into the cells and by used catabolic pathway to convert them into biochemical building blocks and energy (Makela et al. 2018).

The carbon source plays an important role in cell metabolism and cellulase synthesis. In this work, carbon source was obtained from several lignocellulosic biomass as substrates such as rice straw, rice hull, rice bran, and brown rice flour. Prior to use, all substrates were dried, grounded, and sieved at 40 mesh. The size reduction of particles would allow the increased surface area of the substrates, thus enabling fungi to use them as carbon source for enzyme production. 
The application of different carbon sources as inducer for $\beta$-glucosidase production was remarkably influential for enzyme production. This is due to a difference in amount of components that constitute carbon source. There was a clear variation regarding the production of $\beta$-glucosidase as a result of different substrates used (Figure 1.A). Rice bran was also found as the best carbon source for $\beta$-glucosidase production in comparison with other sources, such as rice straw, rice hull, and brown rice flour. Production of $\beta$ glucosidase from $A$ niger strain InaCC F57 using rice bran as a substrate reached the highest activity $(2.45 \pm 0.16$ $\mathrm{U} / \mathrm{mL}$ ), while the lowest one was attributed to rice hull, with activity of $0.41 \pm 0.01 \mathrm{U} / \mathrm{mL}$. Enzyme production using rice straw substrate did not statistically differ $(\alpha=$ 0.05 ) from that obtained in brown rice flour substrate.

The different substrates that used for fermentation medium affected soluble protein content in the crude enzyme. There was a relationship between the secretion of soluble protein and production of enzymatic activities (Figure 1.B). The amount of soluble protein present in the crude enzyme reached a maximum level in rice bran substrate, i.e $3.49 \pm 0.33 \mathrm{mg} / \mathrm{mL}$.

The use of rice bran as substrate that produces $\beta$ glucosidase with the highest activity is in accordance with the reported by Raza et al. (2011). They made a selection of agricultural by-products (tea waste, sawdust, wheat bran, wheat straw, and rice straw) as substrate for $\beta$-glucosidase production by co-culture of $A$. niger and $A$. oryzae. The result showed that the maximum production of $\beta$ - glucosidase was obtained when wheat bran was used as substrate. Wheat bran contains protein, fat, fiber, ash, Ca, $\mathrm{Mg}, \mathrm{P}, \mathrm{K}, \mathrm{S}$, and various essential amino acids that are sufficient for fungal growth and enzyme production.

Cellulose is considered as inducer for $\beta$-glucosidase in solid-state fermentation. Rice straw and rice hull are richer in cellulose compared to rice bran, but contain a high content of lignin. Presence of lignin makes the cellulose more resistant against microbial attack, thus reducing accessibility of fungi to use it for $\beta$-glucosidase production. On the other hand, brown rice flour and rice bran contain less lignin, but cellulose content in the flour is lower than that in rice bran, leading to lower production of $\beta$ glucosidase. Composition of cellulose, hemicellulose, and lignin in the lignocellulosic biomass substrates is presented in Table 1 .

Rice bran has the highest hemicellulose content $(43.27 \%)$ compared to other substrates. Hemicellulose is composed of mainly pentoses (like xylose and arabinose) and hexoses (like mannose, glucose, and galactose) (Brodeur et al. 2011). The fungus A. niger can utilize biomass polysaccharides (hemicellulose) as carbon source for fungal growth by degrading these compounds into monomeric sugars. Furthermore, these monomeric sugars were transported into the cells and by used catabolic pathway to convert them into biochemical building blocks and energy (Makela et al. 2018). The fungus A. niger can use these building blocks and energy for fungal growth and increased $\beta$-glucosidase production.

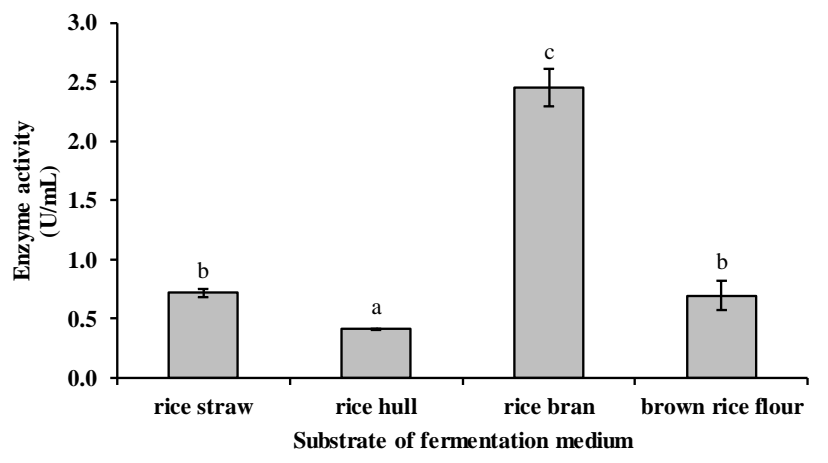

$\mathbf{A}$

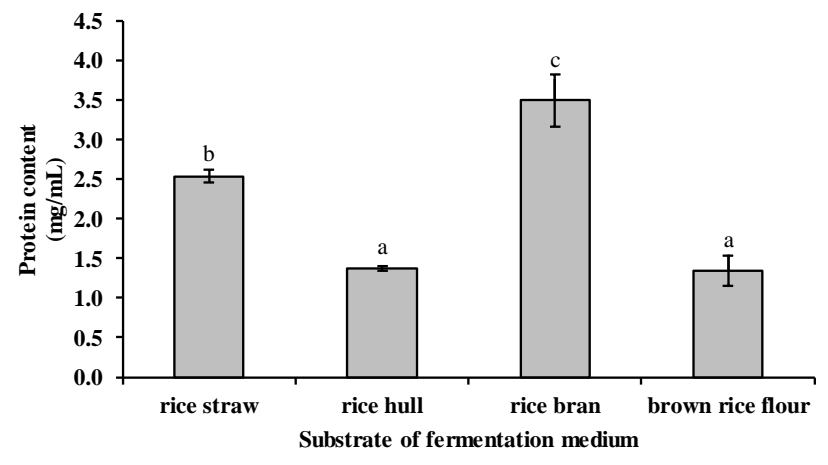

B

Figure 1. Effect of substrate to: A. $\beta$-glucosidase production; B. Protein content of $\beta$-glucosidase crude enzyme from A. niger InaCC F57

Table 1. Chemical composition of lignocellulosic biomass

\begin{tabular}{lcccc}
\hline \multicolumn{1}{c}{ Lignocellulosic } & \multicolumn{4}{c}{ Chemical composition (\%) } \\
\cline { 2 - 5 } \multicolumn{1}{c}{ Biomass } & Crude fiber & Cellulose & Hemicellulose & Lignin \\
\hline Rice straw & $28.66 \pm 0.22$ & $29.11 \pm 0.19$ & $22.74 \pm 0.13$ & $4.13 \pm 0.02$ \\
Rice hull & $42.22 \pm 0.12$ & $35.91 \pm 0.43$ & $14.06 \pm 0.00$ & $13.57 \pm 0.21$ \\
Rice bran & $18.09 \pm 0.09$ & $5.61 \pm 0.68$ & $43.27 \pm 1.48$ & ND \\
Brown rice flour & $10.29 \pm 0.19$ & $3.38 \pm 0.06$ & $19.04 \pm 0.19$ & ND \\
\hline
\end{tabular}

Note: ND: not detected 
The main components of lignocellulosic biomass (cellulose, hemicellulose, and lignin) were analyzed using the Chesson method (Datta, 1981). Determination of these components by this method done by gradual fractionation of lignocellulose polysaccharides using hot water, $0.5 \mathrm{M}$ $\mathrm{H}_{2} \mathrm{SO}_{4}$, and $72 \%$ (v/v) $\mathrm{H}_{2} \mathrm{SO}_{4}$. The weight lost during the fractionation stage is the weight of hemicellulose, cellulose, and lignin. Chesson method is a gravimetric analysis for the quantitative determination of samples based on the mass of a solid. Mostly, collected dried solids are weighed with an analytical balance. Gravimetric method can provide precise analysis by carefully performed, especially while weighing. Determination of lignocellulosic biomass components using gravimetric analysis does not require expensive equipment, provides less instrumental error, and exists in scientific literature (Ayeni et al. 2015).

\section{Effect of initial fermentation pH on enzyme production}

The hydrogen ion concentration ( $\mathrm{pH}$ value) of fermentation medium influenced the growth of fungi, either directly by its action on the cell surfaces or indirectly by its effect on the nutrient's availability (Abubakar et al. 2013). Figure 2.A exhibits the effect of $\mathrm{pH}$ level of media at initial stage of fermentation on production of $\beta$-glucosidase from A. niger InaCC F57. Rice bran was used as support in fermentation, with various $\mathrm{pH}$ levels of 2.0, 3.0, 4.0, 5.0, $5.5,6.0$, and 7.0. The $\mathrm{pH}$ level was only measured at initial stage of fermentation, while $\mathrm{pH}$ level during fermentation was not controlled.

Maximum $\beta$-glucosidase production was found at $\mathrm{pH}$ 2.0 , with activity of $3.72 \pm 0.12 \mathrm{U} / \mathrm{mL}$. This value did not statistically differ from that obtained in $\mathrm{pH} 3.0(\alpha=0.05)$, resulting in an activity of $3.54 \pm 0.16 \mathrm{U} / \mathrm{mL}$. Meanwhile, the lowest $\beta$-glucosidase production was obtained at $\mathrm{pH} 5$, 6 , and 7 , with no significant difference $(\alpha=0.05)$ among these $\mathrm{pH}$ levels.

Most filamentous fungi will grow optimally and secrete high production of enzymes in acidic $\mathrm{pH}$ (Zahoor et al. 2011). This might be due to the fact that alkaline $\mathrm{pH}$ has inhibitory effect on fungal growth and enzyme production.
Besides cultivation of fungi at an unfavorable $\mathrm{pH}$ will limit the growth rate and enzyme production by reducing the accessibility of cellulose and hemicellulose substrate (Bakri et al. 2008).

Compared to another report, there is a difference in $\mathrm{pH}$ level for maximum production of $\beta$-glucosidase. Zahoor et al. (2011) produced $\beta$-glucosidase from $A$. niger NRRL 599 under liquid state fermentation using wheat bran at $\mathrm{pH}$ levels ranging from 4.0-7.0. The results showed that maximum production was achieved at $\mathrm{pH}$ 5.5. While Qian et al. (2012) who produced $\beta$-glucosidase from A. niger AS 3.4309 using wheat bran substrate obtained the maximum production $\mathrm{pH}$ at 6.0 . The amount of soluble protein in crude enzyme was not significantly different $(\alpha=0.05)$ at the initial fermentation $\mathrm{pH}$ of 2.0-5.0 with a range of values 4.29-4.45 $\mathrm{mg} / \mathrm{mL}$. The soluble protein content reached maximum level at $\mathrm{pH}$ 6.0, i.e. $5.67 \mathrm{mg} / \mathrm{mL}$ (Figure 2.B).

\section{Effect of fermentation incubation time on enzyme production}

Incubation time can be an influential factor for production of $\beta$-glucosidase. In the experiment, incubation was performed in 1-9 days to find maximum production of crude enzyme from A. niger InaCC F57. We found that more enzyme was produced as longer period of incubation, but the production was decreased after reaching optimum incubation time (Figure 3).

The results showed that the highest yield of $\beta$ glucosidase was achieved on day 5, resulting in activity of $4.93 \pm 0.15 \mathrm{U} / \mathrm{mL}$. This value was not significantly different from that obtained in day 6 (activity of $4.63 \pm$ $0.08 \mathrm{U} / \mathrm{mL}$ ) and day 7 (activity of $4.40 \pm 0.13 \mathrm{U} / \mathrm{mL}$ ) at $\alpha=$ 0.05 . On day 9 , there was a decrease in the activity of 3.71 $\pm 0.43 \mathrm{U} / \mathrm{mL}$. The production of $\beta$-glucosidase decreased after reaching optimum incubation time due to depletion of macro- and micronutrient in the fermentation media; thus, the physiological activities of fungi were markedly inhibited, which in turn could deactivate fungal cellular activities responsible for enzyme secretion (Ikram-ul-Haq et al. 2006).

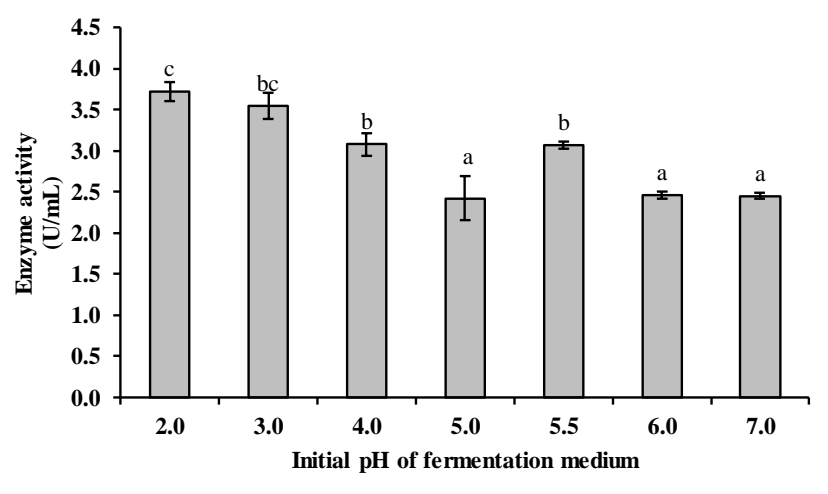

$\mathbf{A}$

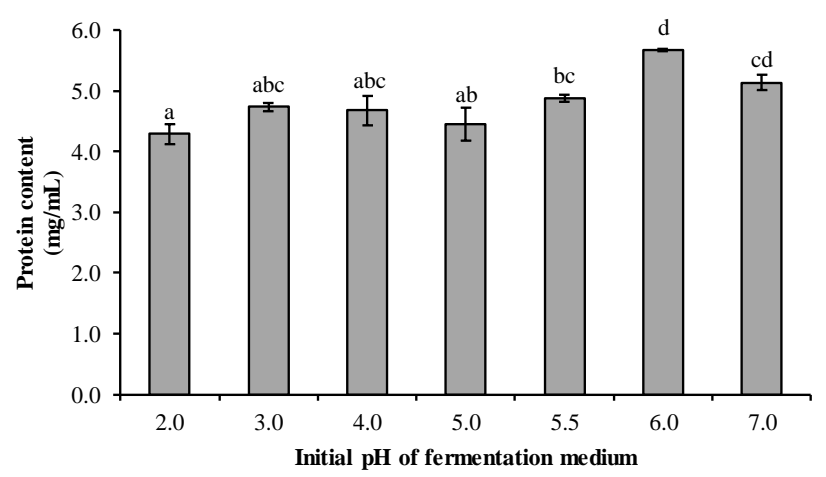

B

Figure 2. Effect of initial fermentation $\mathrm{pH}$ on: A. $\beta$-glucosidase production; B. Protein content of $\beta$-glucosidase crude enzyme from $A$. niger InaCC F57. 
Additionally, the result seemed to be similar to that obtained by Julia et al. (2016) who produced $\beta$-glucosidase from A. niger NRRL 3 under solid-state fermentation (SSF) using soybean hulls and waste paper as substrate. The result showed that the maximum enzyme activity of soybean hulls $(0.984 \mathrm{U} / \mathrm{mL})-1.7$ times greater than that obtained in waste paper-was reached in fermentation period of 4 days at $30^{\circ} \mathrm{C}$. Furthermore, Raza et al. (2011) performed co-culture of $A$. niger and $A$ oryzae to produce $\beta$-glucosidase during 1-5 days of fermentation period using wheat bran as substrate. Their experiment concluded that optimum incubation time was observed on day 3 .

The amount of soluble protein reached the maximum level at two and three days after fermentation, i.e. 6.94 and $7.65 \mathrm{mg} / \mathrm{mL}$. Furthermore, the protein soluble content decreased with increase in incubation period and was not significantly different $(\alpha=0.05)$ in day 4 to 9 of incubation with protein levels ranging from 4.36 to $5.22 \mathrm{mg} / \mathrm{mL}$ (Figure 3.B).

Effect of water to substrate ratio on enzyme production

Water content in substrate may affect enzyme production during solid-state fermentation. The effect of substrate to water ratio on production of $\beta$-glucosidase from $A$. niger InaCC F57 was exhibited in Figure 4. In this experiment, rice bran $(10 \mathrm{~g})$ as substrate was mixed with different amounts of distilled water, i.e. 5, 10, 15, 20, 25 and $30 \mathrm{~mL}$.

The results showed that the lowest yield of $\beta$ glucosidase was achieved at water to substrate ratio of 0.5 : 1 , resulting in activity of $3.06 \pm 0.13 \mathrm{U} / \mathrm{mL}$. The highest yield of $\beta$-glucosidase was achieved at water to substrate ratio of $1.5: 1$ with an activity of $4.99 \pm 0.13 \mathrm{U} / \mathrm{mL}$, although it is not significantly different from ratio of $1: 1$ and $2: 1(\alpha=0.05)$. The addition of distilled water up to 25 and $30 \mathrm{~mL}$ caused a reduction of enzyme activity. Therefore the production of $\beta$-glucosidase by $A$. niger is better to use SSF which has lower moisture content compared to $\mathrm{SmF}$ which high moisture content. This finding was in accordance with that reported by Raza et al. (2011), in which mixed culture fermentation consisting of $A$. niger and A. oryzae was used for production of $\beta$ glucosidase. As a result, maximum production was obtained at ratio of $1: 1$, namely $10 \mathrm{~g}$ wheat bran and 10 $\mathrm{mL}$ solvent.

The highest yield of soluble protein content in $\beta$ glucosidase crude enzyme was achieved at water to substrate ratio of $1: 2$, i.e. $5.86 \mathrm{mg} / \mathrm{mL}$. The increase of water content in the fermentation medium substrate caused a reduction in soluble protein content. The lowest of soluble protein content was achieved at water to substrate ratio of 3 : 1, i.e. $3.47 \mathrm{mg} / \mathrm{mL}$ (Figure 4.B).

\section{Effect of incubation temperature on enzyme production}

Incubation temperature is regarded as one of the most important features for enzyme production in solid-state fermentation. In the experiment, fermentation was performed under three different temperatures, i.e. 28, 32, and $36^{\circ} \mathrm{C}$. Table 2 presents the effects of incubation temperature on activity, protein content, and specific activity of $\beta$-glucosidase crude enzyme. The results showed that maximum production of $\beta$-glucosidase was achieved at incubation temperature of $32^{\circ} \mathrm{C}$ with an activity of $3.47 \pm$ $0.36 \mathrm{U} / \mathrm{mL}$. The rising temperature up to $36^{\circ} \mathrm{C}$ caused depletion of the enzyme activity, even though not significantly different from that achieved at $32^{\circ} \mathrm{C}$.

The optimum incubation temperature obtained in this study is quite similar to that reported by Bansal et al. (2012) and Zahoor et al. (2011). In their experiments, A. niger NS-2 was used to produce $\beta$-glucosidase using wheat bran as substrate (Bansal et al. 2012), while Zahoor et al. (2011) produced $\beta$-glucosidase from A. niger NRRL 599, resulting in optimum temperature for enzyme production at $30^{\circ} \mathrm{C}$.

Table 2. Effect of incubation temperature on production of $\beta$ glucosidase crude enzyme

\begin{tabular}{lccc}
\hline $\begin{array}{c}\text { Incubation } \\
\text { temperature } \\
\left({ }^{\circ} \mathbf{C}\right)\end{array}$ & $\begin{array}{c}\text { Activity } \\
(\mathbf{U} / \mathbf{m L})\end{array}$ & $\begin{array}{c}\text { Protein } \\
\text { concentration } \\
(\mathbf{m g} / \mathbf{m L})\end{array}$ & $\begin{array}{c}\text { Specific } \\
\text { activity } \\
(\mathbf{U} / \mathbf{m g} \\
\text { protein) }\end{array}$ \\
\hline 28 & $2.90 \pm 0.34^{\mathrm{a}}$ & $4.70 \pm 0.67^{\mathrm{a}}$ & $0.62 \pm 0.02^{\mathrm{a}}$ \\
32 & $3.47 \pm 0.36^{\mathrm{a}}$ & $4.96 \pm 0.27^{\mathrm{a}}$ & $0.70 \pm 0.03^{\mathrm{a}}$ \\
36 & $2.82 \pm 0.10^{\mathrm{a}}$ & $3.61 \pm 0.03^{\mathrm{a}}$ & $0.78 \pm 0.03^{\mathrm{a}}$ \\
\hline
\end{tabular}

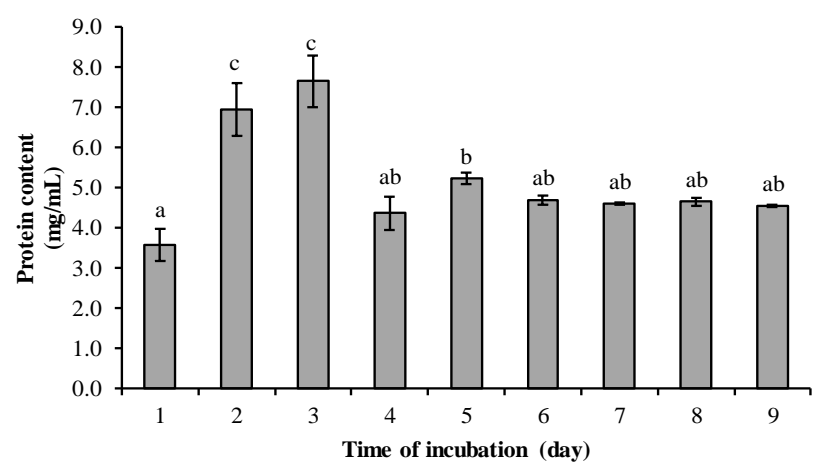

B

Figure 3. Effect of fermentation incubation time on: A. $\beta$-glucosidase production; B. Protein content of $\beta$-glucosidase crude enzyme from A. niger InaCC F57. 


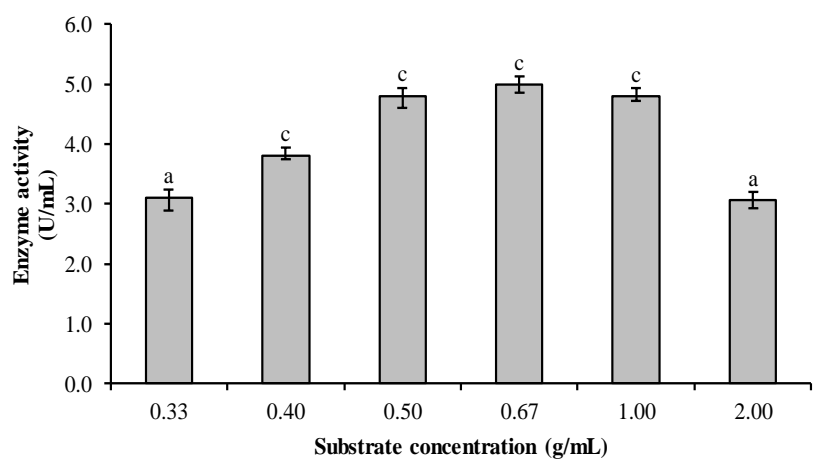

A

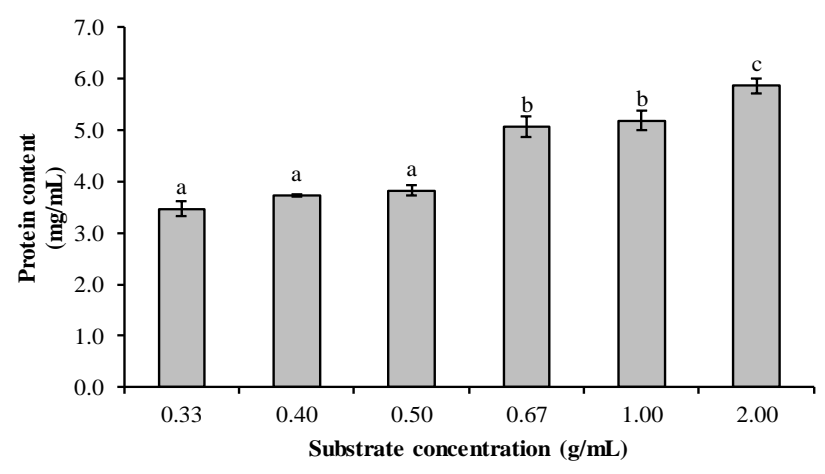

B

Figure 4. Effect of water to substrate ratio on: A. $\beta$-glucosidase production; B. Protein content of $\beta$-glucosidase crude enzyme from A. niger InaCC F57

\section{Effect of Mandels mineral salts solution}

Mandels mineral salts solution is a nutrient source that consists of micronutrients $\left(\mathrm{KH}_{2} \mathrm{PO}_{4}, \mathrm{CaCl}_{2}, \mathrm{MgSO}_{4}\right.$, $\mathrm{FeSO}_{4}, \mathrm{MnSO}_{4}, \mathrm{ZnSO}_{4}, \mathrm{CoCl}_{2}$ ) and macronutrients (urea, ammonium sulfate, peptone) (Mandels and Reese 1957). The nutrient solution was added into medium of $A$. niger InaCC F57 containing rice bran in the optimum fermentation condition $(\mathrm{pH} 2.0$; water to substrate ratio of 1.5 : 1.0 , incubation temperature of $32^{\circ} \mathrm{C}$, fermentation time of 5 days), resulting in improved production of $\beta$ glucosidase, being a $26.22 \%$ greater than that produced in absence of Mandels mineral salts solution. The activity of $\beta$-glucosidase from fermentation with the addition of Mandels mineral salts solution was $3.37 \pm 0.28 \mathrm{U} / \mathrm{mL}$.

The incorporation of Mandels mineral salts solution in fermentation system for $\beta$-glucosidase production was also reported by Raza et al. (2011). The study aimed for selection of 10 different diluents (M-1 until M-10) for $\beta$ glucosidase production using mixed culture of $A$. niger and A. oryzae by solid-state fermentation. M-2 is the Mandels mineral salt solution, while the other 9 diluents are mineral salt solutions with different compositions from the Mandels mineral salt solution. The result showed that presence of M-2 in fermentation medium could produce a higher amount of $\beta$-glucosidase crude enzyme in comparison with other diluents examined. This might be due to the fact that M-2 medium contains all additional nutrients, organic (urea and peptone) and inorganic (ammonium sulfate) nitrogen sources and high concentration of Tween 80 that have been reported to increase $\beta$-glucosidase production (Chellapandi and Jani 2008). Lee et al. (2017) found that the addition of surfactant, Tween 80, and polyethylene glycol on growth medium of Trichoderma harzianum KUC1716 able to increase cellulose production. These surfactants resulted in a morphological shift from an aggregated to a more dispersed form, which improves fungus accessibility to nutrients and improves the enzyme production.

In conclusion, rice straw, rice hull, rice bran, and brown rice flour are promising fermentation substrates for production of $\beta$-glucosidase. The results suggested that rice bran appeared to be the best-suited inducer for obtaining appreciable yield of $\beta$-glucosidase from local isolate of $A$. niger InaCC F57, as also exerted by rice straw, rice hull, and brown rice flour, respectively. The fermentation could reach the highest yield of $\beta$-glucosidase at initial $\mathrm{pH}$ fermentation of 2.0, incubation time of 5 days, water to substrate ratio of $1.5: 1.0$, and incubation temperature of $32^{\circ} \mathrm{C}$. Enrichment of Mandels mineral salts solution could effectively raise activity of $\beta$-glucosidase crude enzyme up to $26.22 \%$, which is the highest increment compared with absence of the solution. All the evaluated factors; the carbon source, $\mathrm{pH}$ medium, incubation time, water to substrate ratio, fermentation temperature, and Mandels mineral salts solution affect the increase of $\beta$-glucosidase activity.

\section{ACKNOWLEDGEMENTS}

The authors would like to thank Ministry of Research, Technology, and Higher Education, Republic of Indonesia, for financially supporting our research under scheme of Karyasiswa Scholarship for Postgraduate Program.

\section{REFERENCES}

Abubakar A, Suberu HA, Bello IM, Abdulkadir R, Daudu OA, Lateef AA. 2013. Effect of $\mathrm{pH}$ on mycelial growth and sporulation of Aspergillus parasiticus. J Plant Sci 1 (4): 64-67.

Ang SK, Shaza EM, Adibah Y, Suraini AA, Madihah MS. 2013. Production of cellulases and xylanase by Aspergillus fumigatus SK1 using untreated oil palm trunk through solid-state fermentation. $\begin{array}{lllll}\text { Process } & \text { Biochem } 48 & (9): & 1293-1302 . & \text { DOI: }\end{array}$ 10.1016/j.procbio.2013.06.019

Asha P, Divya J, Bright Singh IS. 2016. Purification and characterization of processive-type endoglucanase and $\beta$-glucosidase from Aspergillus ochraceus MTCC 1810 through saccharification of delignified coir pith to glucose. Bioresour Technol 213: 245-248. DOI: 10.1016/j.biortech.2016.03.013

Ayeni AO, Adeeyo OA, Oresegun OM, Oladimeji TE. 2015. Compositional analysis of lignocellulosic materials: Evaluation of an economically viable method suitable for woody and non-woody biomass. Am J Eng Res 4 (4): 14-19.

Bansal N, Tewari R, Soni R, Soni SK. 2012. Production of cellulases from Aspergillus niger NS-2 in solid-state fermentation on agricultural and kitchen waste residues. Waste Manag 32 (7): 1341-1346. DOI: 10.1016/j.wasman.2012.03.006 
Binod P, Sindhu R, Janu KV, Pandey A. 2019. Hydrolysis of cellulosic and hemicellulosic biomass. In: Pandey A, Larroche C, Dussap CG Gnansounou E, Khanal SK, Ricke S (eds). Biofuels: Alternative Feedstocks and Conversion Processes for the Production of Liquid and Gaseous Biofuels. Elsevier Inc., Nederlands

Bakri Y, Jawhar M, Arabi MIE. 2008. Improvement of xylanase production by Cochliobolus sativus in submerged culture. Food Technol Biotechnol 46 (1): 116-118.

Biro Kerjasama dan Komunikasi Publik Kemenristekdikti dan Humas BPPT. 2017. Menristekdikti Resmikan Fasilitas Unit Produksi Enzim BPPT - PT Petrosida, Gresik. [Indonesian]

Brodeur G, Yau E, Badal K, Collier J, Ramachandran KB, Ramakhrisnan S. 2011. Chemical and physicochemical pretreatment of lignocellulosic biomass: A review. Enzyme Res. DOI: $10.4061 / 2011 / 787532$

Cao P, Wang L, Wang Y, Zhou N, Chen Y. 2015. Alkali-tolerant $\beta$ glucosidase produced by newly isolated Aspergillus fumigatus WL002 from rotten wood. Intl Biodeter Biodegr 105: 276-282. DOI: 10.1016/j.ibiod.2015.09.010

Chellapandi P, Jani HM. 2008. Production of endoglucanase by the native strains of Streptomyces isolates in submerged fermentation. Braz J Microbiol $\quad 39$ (1): 122-127. DOI: 10.1590/S1517838220080001000026

Datta R. Acidogenic fermentation of lignocellulose-acid yield and conversion of components. 1981. Biotechnol Bioeng 23 (9): 2167 2170. DOI: 10.1002/bit.260230921

da Silva TM, Pessela BC, da Silva JCR, Lima MS, Jorge JA, Guisan JM, Polizeli MLTM. 2014. Immobilization and high stability of an extracellular $\beta$-glucosidase from Aspergillus japonicus by ionic interactions. J Mol Catal B Enzym 104: 95-100. DOI: 10.1016/j.molcatb.2014.02.018

Elshafei AM, Hassan MM, Morsi NM, Elghonamy DH. 2011. Purification and some kinetic properties of $\beta$-glucosidase from Aspergillus terreus NRRL 265. Afr J Biotechnol 10 (84): 19556-19569. DOI 10.5897/AJB10.2617

Faisal PA, Benjamin S. 2016. Optimization of parameters for the production of cellulase from Achromobacter xylosoxidans BSS4 by solid-state fermentation. Electr J Biol 12 (4): 432-437.

Frisvad JC, Moller LLH, Larsen TO, Kumar R, Arnau J. 2018. Safety o the fungal workhorses of industrial biotechnology: update on the mycotoxin and secondary metabolite potential of Aspergillus niger Aspergillus oryzae, and Trichoderma reesei. Appl Microbiol Biotechnol 102 (22): 9481-9515.

Gonzales-Pombo P, Farina L, Carrau F, Batista-Viera F, Brena B.M. 2011. A Novel extracellular $\beta$-glucosidase from Issatchenkia terricola: Isolation, immobilization and application for aroma enhancement of white muscat wine. Process Biochem 46 (1): 385389. DOI: $10.1016 /$ j.procbio.2010.07.016

Grover A, Arora M, Sarao LK. 2013. Production of fungal amylase and cellulase enzymes via solid-state fermentation using Aspergillus oryzae and Trichoderma reesei. Int J Advance Res Technol 2 (8).

Herr D, Baumer F, Dellweg $H$. Purification and properties of an extracellular $\beta$-glucosidase from Lenzites trabea. 1978. Appl Microbiol Biotechnol 5 (1): 29-36.

Ikram-ul-Haq, Javed MM, Khan TS. 2006. An innovative for hyperproduction of cellulolytic and hemicellulolytic enzymes by consortium of Aspergillus niger MSK-1 and Trichoderma viride MSK-10. Afr J Biotechnol 5 (8): 609-614

Irfan M, Mushtaq Q, Tabssum F, Shakir HA, Qazi JI. 2017. Carboxymethyl cellulase production optimization from newly isolated thermophilic Bacillus subtilis K-18 for saccharification using response surface methodology. AMB Express 7: 29. DOI: 10.1186/s13568-017-0331-3

Jampala P, Tadikamalla SM, Preethi M, Ramanujam S, Uppuluri KB 2017. Concurrent production of cellulase and xylanase from Trichoderma reesei NCIM 1186: Enhancement of production by desirability-based multi-objective method. 3 Biotech 7 (1): 14. DOI 10.1007/s13205-017-0607-y

Julia BG, Belen AM, Georgina B, Beatriz F. 2016. Potential use of soybean hulls and waste paper as supports in SSF for cellulase production by Aspergillus niger. Biocatalys Agric Biotechnol 6: 1-8. DOI: 10.1016/j.bcab.2016.02.003

Krisch J, Tako M, Papp T, Vagvolgyi C. 2010. Characteristics and potential use of $\beta$-glucosidase from Zygomycetes. In: Mendez-Vilas (ed.). Current Research, Technology and Education Topics in Applied
Microbiology and Microbial Biotechnology, Formatex Research Center, Spain

Kumar V, Singh D, Sangwan P, Gill PK. 2014. Global market scenario of industrial enzymes. In: Beniwal V, Sharma AK (eds.). Industrial Enzymes: Trends, Scope and Relevance. Nova Science Publishers, Inc., New York.

Lee H, Lee YM, Heo YM, Hong JH, Jang S, Anh BJ, Lee SS, Kim JJ. 2017. Optimization of fungal enzyme production by Trichoderma harzianum KUC1716 through surfactant-induced morphological changes. Mycobiology 45 (1): 48-51. DOI: 10.5941/MYCO.2017.45.1.48

Lowry OH, Rosebrough NJ, Farr AL, Randall RJ. 1951. Protein measurement with the Folin Phenol Reagent. J Biol Chem 193: 265275.

Maitan-Alfenas GP, Visser EM, Guimaraes VM. 2015. Enzymatic hydrolysis of lignocellulosic biomass: Converting food waste in valuable products. Curr Opin Food Sci 1: 44-49. DOI: 10.1016/j.cofs.2014.10.001

Makela MR, Aguilar-Pontes MV, van Rossen-Uffink D, Peng M, de Vries RP. 2018. The fungus Aspergillus niger consumes sugars in a sequential manner that is not mediated by the carbon catabolite repressor CreA. Sci Rep 8: 6655. DOI: 10.1038/s41598-018-25152-x

Manan MA, Webb C. 2017. Design aspects of solid-state fermentation as applied to microbial bioprocessing. J Appl Biotechnol Bioengineer 4 (1): 511-532. DOI: 10.15406/jabb.2017.04.00094

Mandels M, Reese ET. 1957. Induction of cellulase in Trichoderma viride as influenced by carbon sources and metals. J Bacteriol 73: 269-278.

Pirota RD, Delabona PS, Farinas CS. 2014. Simplification of the biomass to ethanol conversion by using the whole medium of filamentous fungi cultivated under solid-state fermentation. Bioenerg Res 7: 744752. DOI: $10.1007 / \mathrm{s} 12155-013-9406-4$

Polyanna NH, Porto TS, Moreira KA, Pinto GA, Cristina MS, Ana LF. 2011. Cellulase production by Aspergillus japonicas URM5620 using waste from castor bean (Ricinus communis L.) under solid-state fermentation. Appl Biochem Biotechnol 165 (3-4): 1057-1067. DOI: 10.1007/s12010-011-9321-0.

Qian LC, Fu SJ, Zhou HM, Sun JY, Weng XY. 2012. Optimization of fermentation parameters for $\beta$-glucosidase production by Aspergillus niger. J Anim Vet Adv 11 (5): 583-591. DOI: 10.3923/javaa.2012.583.591

Raza F, Raza NA, Hameed U, Haq IU, Mariam I. 2011. Solid-state fermentation for the production of $\beta$-glucosidase by co-culture of Aspergillus niger and A. oryzae. Park J Bot 43 (1): 75-83.

Rivera-Espinoza Y, Muriel P. 2013. Vanilla. Global Adv Res J Microbiol 2 (11): 203-210.

Saini A, Aggarwal NK, Yadav A. 2017. Cost-effective cellulase production using Parthenium hysterophorus biomass as an unconventional lignocellulosic substrate. 3Biotech 7: 12. DOI: $10.1007 / \mathrm{s} 13205-017-0604-1$

Shobana P, Maheswari NM. 2013. Production of cellulase from Aspergillus fumigatus under submerged and solid-state fermentation. Intl J Adv Pharm Biol Chem 2 (4): 595-599.

Singhania RR, Sukumaran RK, Patel AK. 2010. Advancement and comparative profiles in the production technologies using solid-state and submerged fermentation for microbial cellulases. Enzyme Microb Technol 46: 541-549. DOI: 10.1016/j.enzmictec.2010.03.010

Singhania RR, Patel AK, Sukumaran RK, Larroche C, Pandey A. 2013. Role and significance of beta-glucosidases in the hydrolysis of cellulose for bioethanol production. Bioresour Technol 127: 500-507. DOI: 10.1016/j.biortech.2012.09.012

Sørensen A, Lubeck M, Lubeck PS, Ahring BK. 2013. Fungal betaglucosidases: A bottleneck in industrial use of lignocellulosic materials. Biomolecules 3 (3): 612-631. DOI: 10.3390/biom3030612rensen,

Sørensen A, Andersen JJ, Ahring BK, Teller PJ, Lubeck M. 2014. Screening of carbon sources for beta-glucosidase production by Aspergillus saccharolyticus. Intl Biodeter Biodegr 93: 78-83. DOI: 10.1016/j.ibiod.2014.05.011

Watanabe A, Suzuki M, Ujiie S, Gomi K. 2016. Purification and enzymatic characterization of a novel $\beta-1,6-$ Glucosidase from Aspergillus oryzae. J Biosci Bioeng 121 (3): 259-264. DOI: 10.1016/j.jbiosc.2015.07.011

Yang X, Mai R, Shi P, Huang H, Bai Y, Wang Y, Yang P, Fan Y, Yao B. 2014. Molecular characterization of a highly-active thermophilic $\beta$ glucosidase from Error! Bookmark not defined.P1 and its 
application in the hydrolysis of soybean isoflavone glycosides. PLoS One 9 (9): e106785. DOI: 10.1371/journal.pone.0106785

Zahoor S, Javed MM, Aftab S, Latif F, ul-Haq I. 2011. Metabolic engineering and thermodynamic characterization of an extracellular $\beta$-glucosidase produced by Aspergillus niger. Afr J Biotechnol.10 (41): 8107-8116. DOI: $10.5897 /$ AJB11.186
Zhang T, Fang K, Ni H, Li T, Li LJ, Li QB, Chen F. 2020. Aroma enhancement of instant green tea infusion using $\beta$-glucosidase and $\beta$ xylosidase. Food Chem 315 (15): 126287. DOI: 10.1016/j.foodchem.2020.126287.

Zhao CH, Liu X, Zhan T, He J. 2018. Production of cellulase by Trichoderma reesei from pretreated straw and furfural residues. RSC Adv 8: 36233-36238. DOI: 10.1039/C8RA05936E. 